\title{
PENGARUH MOTIVASI BELAJAR, SARANA BELAJAR, DAN PERCAYA DIRI TERHADAP HASIL BELAJAR IPS SISWA PENERIMA BSM (BANTUAN SISWA MISKIN) SMP NEGERI DI SURABAYA
}

\author{
Murtiningsih, SMPN 43 Surabaya \\ murtiningsih2010@gmail.com
}

\begin{abstract}
ABSTRAK
Penelitian ini bertujuan untuk mengetahui (1) Pengaruh motivasi belajar terhadap hasil belajar siswa (2) Pengaruh sarana belajar terhadap hasil belajar siswa (3) Pengaruh percaya diri terhadap hasil belajar siswa (4) Pengaruh motivasi belajar, sarana belajar, dan percaya diri terhadap hasil belajar siswa. Penelitian ini menggunakan pendekatan kuantitatif. Analisis yang digunakan analisis regresi linier berganda. Populasi penelitian sebanyak 150 siswa yang diambil secara random sampling sebanyak 110 siswa di SMP Negeri 39, 41, dan 43 Surabaya Tahun Ajaran 2014-2015. Hasil penelitian menunjukkan (1) Ada pengaruh motivasi belajar terhadap hasil belajar siswa (2) Ada pengaruh sarana belajar terhadap hasil belajar siswa (3) Ada pengaruh percaya diri terhadap hasil belajar siswa (4) Ada pengaruh motivasi belajar, sarana belajar, dan percaya diri terhadap hasil belajar siswa penerima BSM (Bantuan Siswa Miskin) SMP Negeri di Surabaya. Berdasarkan penelitian dapat disimpulkan bahwa motivasi belajar, sarana belajar, dan percaya diri secara simultan berpengaruh signifikan terhadap hasil belajar siswa, yaitu 94,4\% sedangkan 5,6\% dipengaruhi oleh variabel lain di luar variabel yang diteliti. Untuk menutupi kekurangan tersebut, dapat dilakukan dengan cara mengajar dengan metode yang bervariasi dan sesuai dengan materi yang diajarkan dengan mengaitkan materi IPS dalam kehidupan sehari-hari, sarana belajar dilengkapi dan menumbuhkan rasa percaya diri siswa, sehingga hasil belajarnya meningkat.
\end{abstract}

Kata Kunci: Motivasi Belajar, Sarana Belajar, Percaya diri dan Hasil Belajar.

\begin{abstract}
This research aims to know (1) the influence of learning motivation towards learning outcomes students (2) influence of a learning tool toward student learning outcome (3) influence of confidence against a student learning outcome (4) influence of learning motivation, learning tools, and confident against the learning outcomes of students. This research uses a quantitative approach. Analysis of the multiple linear regression analysis was used. Population studies as many as 150 students taken in random sampling as much as 110 students in Junior High School State 39, 41, and 43 Surabaya school year 2014-2015. The results showed (1) there is the influence of learning motivation towards learning outcomes students (2) there is the influence of the means of learning towards student learning


outcome (3) there are confident against influence student learning outcomes (4) there is the influence of learning motivation, learning tools, and confident against the results of student learning receiver BSM (poor students coupon) junior high school state Surabaya. Based on research it can be concluded that the motivation of learning, learning tools, and simultaneous confidence effect significantly to student learning outcomes, namely 94.4 whereas 5.6 is affected by other variables outside of the variables examined. To cover the shortfall, it can be done by way of teaching with the methods vary according to the material being taught by associate Social Science material in everyday life, learning tools are fitted and foster the confidence of students, so that the results of his studies.

Keywords: Motivation, Means Learning, Confident and Learning Outcomes.

\section{PENDAHULUAN}

Pemerintah Indonesia dalam Undang-undang Dasar Republik Indonesia Tahun 1945 dalam Pasal 31 ayat (1) telah mengamanatkan bahwa setiap warga negara berhak untuk mendapatkan pendidikan untuk mengembangkan potensi yang dimiliki secara optimal.

Menurut UU No. 20 tahun 2003 Pendidikan adalah usaha sadar dan terencana untuk mewujudkan suasana belajar dan proses pembelajaran agar peserta didik secara aktif mengembangkan potensi dirinya untuk memiliki kekuatan spiritual keagamaan, pengendalian diri, kepribadian, kecerdasan, akhlak mulia, serta ketrampilan yang diperlukan dirinya, masyarakat, bangsa, dan negara.

Ki Hajar Dewantara, bapak Pendidikan Nasional Indonesia, menyatakan bahwa Pendidikan adalah tuntutan di dalam hidup tumbuhnya anak-anak, adapun maksudnya, pendidikan yaitu menuntun segala kekuatan kodrat yang ada pada anak-anak itu, agar mereka sebagai manusia dan sebagai anggota masyarakat dapatlah mencapai keselamatan dan kebahagiaan setinggitingginya. Pendidikan adalah usaha sadar untuk menyiapkan peserta didik melalui kegiatan bimbingan, pengajaran, dan atau latihan bagi peranannya di masa yang akan datang.

Pendidikan merupakan suatu aspek kehidupan yang sangat mendasar bagi pembangunan bangsa suatu negara. Dalam penyelenggaraan pendidikan di sekolah yang melibatkan guru sebagai pendidik dan siswa sebagai peserta didik, diwujudkan dengan adanya interaksi belajar mengajar atau proses pembelajaran (Iskandar, 2009)

Upaya pemerintah dalam rangka peningkatan mutu pendidikan di Indonesia telah ditempuh melalui berbagai strategi, akan tetapi hasil pembangunan pendidikan Indonesia sampai saat ini masih menjadi "catatan merah". Indikator rendahnya kualitas pendidikan di Indonesia di atas membuat keprihatinan bagi pemerintah, dalam hal ini Departemen Pendidikan Nasional sebagai lembaga yang paling bertanggung jawab atas keberhasilan pembangunan mutu pendidikan di Indonesia. 
Sementara itu, UU No. 20 Tahun 2003 tentang Sistem Pendidikan Nasional, pasal 5, ayat (1) menyatakan bahwa "Setiap warga negara mempunyai hak yang sama untuk memperoleh pendidikan yang bermutu," dan pasal 11, ayat (1) menyatakan "Pemerintah dan Pemerintah Daerah wajib memberikan layanan dan kemudahan, serta menjamin terselenggaranya pendidikan yang bermutu bagi setiap warga negara tanpa diskriminasi."

Pelaksanaan Wajib Belajar Pendidikan Dasar 9 Tahun dan pemberian akses yang lebih besar kepada kelompok masyarakat yang selama ini dirasakan kurang dapat menjangkau layanan pendidikan dasar. Kebijakan ini dilakukan dikarenakan bersamaan dengan kenaikan harga Bahan Bakar Minyak beberapa tahun terakhir ini yang diikuti dengan kenaikan harga kebutuhan bahan pokok lainnya yang berkorelasi negatif terhadap kemampuan daya beli masyarakat kurang mampu atau miskin, sehingga kondisi semacam ini akan dapat menghambat upaya Penuntasan Program Wajib Belajar Pendidikan Dasar 9 Tahun, hal ini juga diperparah dengan semakin bertambahnya jumlah penduduk miskin. Sehingga kedua permasalahan tersebut mempunyai dampak terhadap penduduk kurang mampu atau miskin akan semakin sulit untuk dapat memenuhi kebutuhan hidupnya khususnya biaya pendidikan.

Salah satu usaha yang digunakan untuk mewujudkan tujuan tersebut adalah meningkatkan prestasi belajar siswa. Pengenalan terhadap faktor-faktor yang mempengaruhi prestasi belajar penting sekali artinya dalam rangka membantu murid dalam mencapai prestasi belajar yang sebaik-baiknya.

Dari seluruh SMP Negeri di Surabaya ada tiga sekolah, SMPN 39, SMPN 41, dan SMPN 43, yang siswanya menerima BSM (Bantuan Siswa Miskin). Berdasarkan pengamatan dari guru di masing-masing sekolah, masih banyak yang mengalami kesulitan belajarnya, motivasinya masih rendah, terlihat dari adanya siswa-siswa yang enggan belajar dan tidak bersemangat dalam menerima pelajaran di kelas. Siswapun belum aktif dalam mengerjakan soal latihan yang diberikan karena sarana belajarnya kurang mendukung. Prestasi yang dicapai siswa masih rendah, karena percaya dirinya masih belum muncul. Akibatnya adalah hasil belajarnyapun menjadi kurang memuaskan karena masih banyak nilai dibawah standar kelulusan.

Menurut Sardiman (2011) motivasi merupakan faktor psikis yang bersifat non-intelektual. Peranannya yang khas adalah dalam hal menumbuhkan gairah agar siswa merasa senang dan semangat untuk belajar.

Motivasi belajar yang dimiliki siswa-siswa dalam setiap kegiatan pembelajaran sangat berperan untuk meningkatkan hasil belajar siswa dalam mata pelajaran tertentu (Nashar, 2004:11). Siswa-siswa tersebut akan dapat memahami apa yang dipelajari dan dikuasai serta tersimpan dalam jangka waktu yang lama. Siswa menghargai apa yang telah dipelajari hingga merasakan kegunaannya didalam kehidupan sehari-hari ditengah-tengah masyarakat.

Faktor penting lain yang mempengaruhi prestasi belajar siswa selain motivasi adalah sarana belajar. Sarana belajar, yaitu peralatan dan perlengkapan yang secara langsung dipergunakan dalam menunjang proses pendidikan, khususnya pada saat proses belajar antara lain berupa alat tulis, buku pelajaran, ruang kelas, perpustakaan, laboratorium, media penyampaian materi dan lain sebagainya. Sarana belajar sangatlah penting dalam menunjang 
kegiatan belajar mengajar, karena semakin lengkap sarana belajar yang dimiliki maka akan membantu mempermudah proses belajar mengajar.

Sarana belajar ikut menentukan keberhasilan belajar siswa. Siswa yang memiliki sarana belajar baik, maka dalam belajarnya akan berjalan lancar dan teratur, sedangkan siswa yang belajar tanpa dibantu dengan sarana belajar yang baik, maka dia akan mendapatkan hambatan dalam menyelesaikan kegiatan belajar. Oleh karena itu sarana belajar merupakan faktor yang tidak bisa diabaikan dalam kegiatan belajar mengajar. Adanya sarana belajar dapat membangkitkan semangat siswa dalam belajar. Dengan tersedianya sarana belajar yang lengkap dan sesuai kebutuhan, maka kemampuan siswa yang sedang belajar dapat meningkat.

Selain Motivasi dan sarana belajar, ada unsur lain yang juga menentukan keberhasilan belajar siswa, yaitu percaya diri.

Percaya diri (self confidence) termasuk salah satu aspek psikologi, merupakan modal untuk meyakini kemampuan dan usaha-usaha yang telah dicapai, juga untuk meningkatkan kualitas belajar siswa. Banyak masalah yang timbul karena seseorang tidak percaya pada dirinya sendiri dan lebih menggantungkan kepercayaannya kepada orang lain.

Hal itulah yang menjadi permasalahan peneliti, sehingga peneliti ingin mengetahui lebih jauh tentang Pengaruh Motivasi Belajar, Sarana Belajar, dan Percaya Diri Terhadap Hasil Belajar IPS Siswa Penerima BSM (Bantuan Siswa Miskin) SMP Negeri di Surabaya..

\section{METODE PENELITIAN}

Pendekatan yang digunakan dalam penelitian ini merupakan pendekatan kuantitatif yang menurut Sugiyono (2011), digunakan untuk meneliti pada populasi atau sampel tertentu. Pendekatan kuantitatif ini nantinya menggambarkan hasil penelitian berupa angka-angka atau hitungan kemudian dijelaskan dengan hubungan atau pengaruhnya. Jadi penelitian ini adalah penelitian yang menjelaskan kedudukan variabbel-variabel yang diteliti serta pengaruh antara satu variabel dengan variabel yang lain.

Populasi dalam penelitian ini diambilkan dari semua siswa (penerima BSM) SMP Negeri di Surabaya, yaitu dari SMP Negeri 39, SMP Negeri 41, dan SMP Negeri 43, yang totalnya berjumlah 150 siswa. Pemilihan sampel dari data populasi di atas, yaitu semua siswa (penerima BSM) SMP Negeri di Surabaya, dengan rincian SMP Negeri 39 sejumlah 50 siswa, dari SMP negeri 41 sejumlah 50 siswa, dan dari SMP Negeri 43 sejumlah 50 siswa dengan teknik Propotional Random. Propotional Random Sampling yaitu teknik pengambilan anggota sampel bila populasi mempunyai anggota atau unsur yang tidak homogen secara proposional (Sugiyono, 2011).

Instrumen penelitian ini semuanya menggunakan angket atau kuisioner. Tiga macam angket akan digunakan untuk menjaring variabel motivasi belajar, fasilitas belajar di rumah, dan percaya diri siswa pada mata pelajaran ekonomi. Setiap butir pertanyaan disediakan tempat alternatif jawaban berdasarkan skala skala Likert, yaitu skala yang digunakan untuk mengukur sikap, pendapat dan persepsi seseorang atau sekelompok orang tertentu tentang fenomena sosial. 
Teknik analisis menggunakan analisis regresi berganda. Uji $\mathrm{F}$ digunakan untuk menguji pengaruh variabel independent motivasi belajar $\left(\mathrm{X}_{1}\right)$, sarana belajar $\left(\mathrm{X}_{2}\right)$, dan percaya diri $\left(\mathrm{X}_{3}\right)$ secara simultan terhadap variabel dependent hasil belajar IPS siswa (Y), Koefisien korelasi ganda dikatakan signifikan

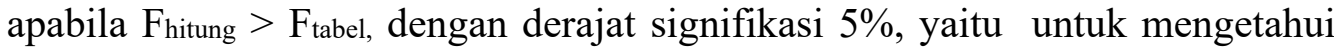
apakah variabel independent motivasi belajar $\left(\mathrm{X}_{1}\right)$, sarana belajar $\left(\mathrm{X}_{2}\right)$, dan percaya diri $\left(\mathrm{X}_{3}\right)$ secara simultan berdampak terhadap variabel dependent hasil belajar IPS siswa (Y).

Dan uji $\mathrm{t}$ statik untuk menguji apakah variabel independent motivasi belajar $\left(\mathrm{X}_{1}\right)$, sarana belajar $\left(\mathrm{X}_{2}\right)$, dan percaya diri $\left(\mathrm{X}_{3}\right)$, secara parsial berdampak terhadap variabel dependent hasil belajar IPS siswa (Y).

\section{HASIL PENELITIAN DAN PEMBAHASAN}

Model persamaan regresi dalam penelitian ini dapat ditulis dalam bentuk persamaan regresi linier berganda sebagai berikut: $\mathrm{Y}=23.411+0.411 \mathrm{X}_{1}+$ $0.814 \mathrm{X}_{2}+0.190 \mathrm{X}_{3}+\mathrm{ei}$

Variabel motivasi belajar $\left(\mathrm{X}_{1}\right)$ sebesar 0.411 , artinya setiap perubahan variabel motivasi belajar $\left(\mathrm{X}_{1}\right)$ akan berpengaruh positif terhadap hasil belajar (Y) sebesar 0.411. Koefisien regresi variabel sarana belajar $\left(\mathrm{X}_{2}\right)$ sebesar 0.814 , artinya setiap perubahan variabel sarana belajar $\left(\mathrm{X}_{2}\right)$ akan berpengaruh positif terhadap hasil belajar (Y) sebesar 0.814. Koefisien regresi variabel percaya diri $\left(\mathrm{X}_{3}\right)$ sebesar 0.190 , artinya setiap perubahan variabel percaya diri $\left(\mathrm{X}_{3}\right)$ akan berpengaruh positif terhadap hasil belajar (Y) sebesar 0.190 .

\section{Coefficients $^{\mathrm{a}}$}

\begin{tabular}{|c|c|c|c|c|c|c|c|c|}
\hline \multirow{2}{*}{\multicolumn{2}{|c|}{ Model }} & \multicolumn{2}{|c|}{$\begin{array}{c}\text { Unstandardized } \\
\text { Coefficients }\end{array}$} & \multirow{2}{*}{$\begin{array}{c}\text { Standardized } \\
\text { Coefficients } \\
\text { Beta }\end{array}$} & \multirow[b]{2}{*}{$\mathrm{t}$} & \multirow[b]{2}{*}{ Sig. } & \multicolumn{2}{|c|}{ Collinearity Statistics } \\
\hline & & $B$ & Std. Error & & & & Tolerance & VIF \\
\hline \multirow[t]{4}{*}{1} & (Constant) & 23,411 & 1,937 & & 12,087 & ,000 & & \\
\hline & Motivasi & 411 & ,059 & ,322 & 6,975 & ,000 & ,250 & 4,005 \\
\hline & Sarana & ,814 & 268 & ,389 & 3,032 & ,003 & ,032 & 30,932 \\
\hline & p_diri & ,190 & ,083 & ,293 & 2,279 & ,025 & ,032 & 31,158 \\
\hline
\end{tabular}

a. Dependent Variable: hsl_belajar

Nilai $R$-square penelitian ini adalah 0.944. Hal ini menunjukkan bahwa hasil belajar IPS siswa penerima BSM (Bantuan Siswa Miskin) SMP Negeri di Surabaya dipengaruhi oleh motivasi belajar, sarana belajar, dan percaya diri sebesar 94.4\%, sedangkan 5,4\% dipengaruhi oleh variabel-variabel lain di luar variabel yang diteliti.

Hasil uji $\mathrm{t}$ menunjukkan bahwa: Variabel motivasi belajar $\left(\mathrm{X}_{1}\right)$ mempunyai nilai signifikan $0.000<0,05$, berarti motivasi belajar berpengaruh terhadap hasil belajar. Variabel sarana belajar $\left(\mathrm{X}_{2}\right)$ mempunyai nilai signifikan $0.003<0,05$, berarti sarana belajar berpengaruh terhadap hasil belajar. Variabel percaya diri $\left(\mathrm{X}_{3}\right)$ mempunyai nilai signifikan $0.025<0,05$, berarti percaya diri berpengaruh terhadap hasil belajar. 
Hasil uji $\mathrm{F}$ dengan nilai signifikansi $0.00<0.05$, maka dinyatakan variabel motivasi belajar $\left(\mathrm{X}_{1}\right)$, sarana belajar $\left(\mathrm{X}_{2}\right)$ dan percaya diri $\left(\mathrm{X}_{3}\right)$ secara simultan berpengaruh terhadap variabel hasil belajar (Y).

\section{Pengaruh motivasi belajar terhadap hasil belajar}

Jawaban responden dengan mean tertinggi adalah pada indikator adanya lingkungan belajar yang kondusif sehingga memungkinkan siswa nantinya dapat belajar dengan baik, yaitu 3,02. Kemudian pada indikator adanya harapan dan cita-cita masa depan dengan mean 3,00. Mean indikator adanya penghargaan dalam belajar adalah 2,99. Mean indikator adanya kegiatan yang menarik dalam belajar yaitu 2,96. Mean indikator adanya dorongan dan kebutuhan dalam belajar yaitu 2,95. Dan terakhir Mean indikator adanya hasrat dan keinginan berhasil yaitu 2,92. Secara umum mean pada semua indikator pada variabel ini dikategorikan agak tinggi. Hal ini berarti bahwa motivasi belajar siswa penerima BSM (Bantuan Siswa Miskin) SMP Negeri di Surabaya mempengaruhi hasil belajar IPS. Hasil penelitian ini juga mendukung teoriteori penelitian terdahulu.

Apabila motif atau motivasi belajar timbul setiap kali belajar, besar kemungkinan hasil belajarnya meningkat (Nashar, 2004). Banyak bakat siswa tidak berkembang karena tidak memiliki motif yang sesuai dengan bakatnya itu. Apabila siswa itu memperoleh motif sesuai dengan bakat yang dimilikinya itu, maka lepaslah tenaga yang luar biasa sehingga tercapai hasil belajar yang semula tidak terduga.

Wlodkowski (2004) menyebutkan bahwa faktor yang mempengaruhi motivasi belajar siswa yaitu budaya, keluarga, sekolah dan anak. Adapun masing-masing diuraikan sebagai berikut:

a. Budaya turut mempengaruhi motivasi belajar siswa. Pembelajaran di sekolah mengajarkan nilai-nilai yang bersifat akademis maupun tradisional. Nilai-nilai ini diteruskan melalui jalur-jalur utama sebagai agama dominan, mitos atau dongeng-dongeng, legislasi politis atas pendidikan, status guru, harapan orang tua atas usaha mempersiapkan anak-anak untuk sekolah.

b. Keluarga merupakan faktor utama yang mempengaruhi motivasi belajar anak karena orang tua berperan sebagai guru pertama dan utama dalam kehidupan seorang anak. Keterlibatan orang tua dalam kelurga baik dalam kehidupan sehari-hari maupun spiritual mampu mendorong dan memberikan inspirasi kepada anak agar berjuang keras untuk mencapai kedamaian batin dan cinta.

Menurut Djalil (2003) motivasi belajar adalah dorongan dari dalam diri siswa dan dari luar diri siswa untuk mengalami perubahan perilaku dalam bentuk pengetahuan, sikap, nilai dan keterampilan. Guru dan lingkungan belajar termasuk didalamnya suasana kelas, bahan, sumber belajar merupan unsur terpenting di luar diri murid. Guru-guru dan apa yang dilakukannya untuk membuat murid-murid mau, mampu dan biasa belajar merupakan motivasi belajar ekstrinsik atau instrumental (datang dari luar).

\section{Pengaruh sarana belajar terhadap hasil belajar}

Jawaban responden dengan mean tertinggi adalah pada indikator prasarana belajar, yaitu 2,82. Kemudian pada indikator adanya sarana belajar, 
yaitu 2,79. Secara umum mean pada semua indikator pada variabel ini dikategorikan sedang. Berdasarkan analisis data yang telah dilakukan, diperoleh hasil bahwa sarana belajar siswa berpengaruh terhadap hasil belajar IPS siswa penerima BSM (Bantuan Siswa Miskin) SMP Negeri di Surabaya. Hasil penelitian ini juga mendukung teori-teori penelitian terdahulu.

Dalam Undang-Undang Sistem Pendidikan Nasional (Sisdiknas) Bab XII

Pasal 45 ayat (1) dinyatakan, setiap satuan pendidikan formal dan nonformal menyediakan sarana dan prasarana yang memenuhi keperluan pendidikan sesuai dengan pertumbuhan dan perkembangan potensi fisik, kecerdasan intelektual, sosial, emosional, dan kejiwaan siswa (Zulkarnain, 2007) "Deklarasi Asosiasi Pengusaha Sarana Pendidikan Indonesia".

Sesuai dengan Keputusan Mendiknas Nomor 053/V/2001, tentang "Pedoman Penyusunan Standar Pelayanan Minimal Penyelenggaraan Persekolahan Bidang Pendidikan Dasar dan Menengah" (2003), untuk lebih terperinci tentang sarana prasarana yaitu lahan/luas tanah yang diperlukan untuk mendirikan sekolah harus memenuhi kebutuhan antara lain :

1. Ruang Pendidikan, meliputi:

a. ruang kelas / belajar

b. ruang perpustakaan

c. tempat bermain / fasilitas olah raga

d. tempat upacara.

2. Ruang Adminstrasi / kantor meliputi :
a. ruang kepala sekolah
b. ruang guru
c. ruang tata usaha.

3. Ruang Penunjang meliputi:

a. ruang UKS

b. ruang ibadah

c. ruang koperasi sekolah/ kantin/ warung

d. kebun sekolah halaman sekolah. Kebun sekolah berada di wilayah permukiman sesuai dengan cakupan wilayah sehingga mudah dijangkau dan aman dari gangguan bencana alam maupun lingkungan yang kurang baik.

Mulyasa (2005) menyatakan bahwa, yang dimaksud dengan sarana belajar adalah peralatan dan perlengkapan yang secara langsung dipergunakan dan menunjang proses pendidikan, khususnya proses belajar mengajar, seperti gedung, ruang kelas, meja kursi, serta alat-alat dan media pengajaran. Adapun yang dimaksud dengan prasarana belajar adalah fasilitas yang secara tidak langsung menunjang jalannya proses pendidikan atau pengajaran, seperti halaman, kebun, taman sekolah, jalan menuju sekolah, tetapi jika dimanfaatkan secara langsung untuk proses belajar mengajar, seperti taman sekolah untuk pengajaran biologi, halaman sekolah sebagai sekaligus lapangan olahraga, komponen tersebut merupakan sarana pendidikan.

\section{Pengaruh percaya diri terhadap hasil belajar}

Jawaban responden dengan mean tertinggi adalah pada indikator prasarana belajar, yaitu 2,82. Kemudian pada indikator adanya sarana belajar, yaitu 2,79. Secara umum mean pada semua indikator pada variabel ini 
dikategorikan sedang. Berdasarkan analisis data yang telah dilakukan, diperoleh hasil bahwa percaya diri berpengaruh positif terhadap hasil belajar siswa. Hasil penelitian ini juga mendukung teori-teori penelitian terdahulu.

Sikap merupakan kecenderungan seseorang dalam melakukan aktifitas.. Tiap-tiap manusia memiliki karakteristik dan kepribadian masing-masing. Sikap percaya diri yang dimiliki seseorangpun juga berbeda-beda.

Menurut Cox (2002) percaya diri secara umum merupakan bagian penting dan karakteristik kepribadian seseorang yang dapat memfasilitasi kehidupan seseorang. Lebih lanjut dikatakan pula bahwa kepercayaan diri yang rendah akan memiliki pengaruh negatif terhadap penampilan seseorang.

Para ahli psikologi memberikan pula definisi tentang kepercayaan diri. Hal ini sebagaimana dikutip Weinberg \& Gould (2003) bahwa "Sport psychologists define self-confidence as the belief that you can successfully perform a desired behaviour". Definisi tersebut, dapat dimaknai bahwa para ahli psikologi mendefinisikan kepercayaan diri sebagai kepercayaan atau keyakinan bahwa seseorang dapat melakukan sesuatu yang diinginkan secara sukses.

Moisi (2006) berpendapat bahwa sikap percaya diri adalah keadaan pemikiran seseorang yang dihadirkan melalui perbuatan. Seseorang dapat lebih percaya diri apabila ia memiliki tujuan dalam hidupnya. Biasanya seseorang yang pasif akan berakir pada ketidak bahagiaan dan merasa tidak nyaman dengan diri mereka sendiri. Sikap percaya diri adalah pendapat yang seseorang miliki mengenai dirinya sendiri (Anonim, 2006).

Menurut Branden (2006). sikap percaya diri adalah sebuah pengalaman dalam keberhasilan untuk menghadapi tantangan kehidupan yang mendasar dan dalam mencapai kebahagiaan.

Sedangkan Huitt (2004) mengartikan bahwa sikap percaya diri adalah aspek emosional dari diri sendiri yang secara umum mengacu pada bagaimana kita merasa, manuali diri kita sendiri.

Berdasarkan pendapat-pendapat tersebut diatas maka sikap percaya diri adalah perilaku/perbuatan yang berdasarkan keyakinan diri sendiri dan tidak dapat dipengaruhi oleh pihak/orang lain dalam pemecahan masalah.

Menurut Mann (dalam Saifudin, 2003) ada beberapa komponen yaitu:

a. Komponen kognitif. Komponen kognitif berisi persepsi, kepercayaan, dan stereotipe yang dimiliki individu mengenai sesuatu. Seringkali komponen kognitif ini dapat disamakan dengan pandangan (opini) terutama apabila menyangkut masalah isue atau problem yang kontroversional.

b. Komponen Afektif. Komponen afektif merupakan perasaan individu terhadap objek sikap dan menyangkut masalah emosi. Aspek emosional inilah yang biasanya berakar paling dalam sebagai komponen sikap dan merupakan aspek yang paling bertahan terhadap pengaruh-pengaruh yang mungkin akan mengubah sikap seseorang.

c. Komponen Perilaku. Komponen perilaku berisi tendensi atau kecenderungan untuk bertindak atau untuk bereaksi terhadap sesuatu dengan cara-cara tertentu.

Ada beberapa cara untuk meningkatka rasa percaya diri menurut Branden (2006), yaitu menekankan pada kekuatan dengan memberikan penghargaan pada diri sendiri akan segala sesuatu yang dilakukan. Keberanian mengambil 
resiko dimana kita mencoba pengalaman baru sebagai sebuah kesempatan untuk belajar bukan sebagai kesempatan untuk menang ataupun kalah, berani berbicara/mengemukakan pendapat sendiri dimana hal ini digunakan sebagai kesempatan untuk menjawab asumsi yang merugikan dan yang terakir adalah mengevaluasi diri sendiri yaitu secara independen mengevaluasi diri sendiri dengan memfokuskan pada bagaimana perasaan kita akan tingkah laku, pekerjaan dan lain sebagainya.

Weinberg \& Gould (2003) lebih menegaskan pentingnya kepercayaan diri dengan menyatakan bahwa: Self-confidence is characterized by high expectancy of success. It can help individuals to arouse positive emotions, facilitate concentration, set goals, increase effort, focus their game strategies, and maintain momentum in essense, confidence can influence affect, behavior, and cognitions.

Penegasan di atas bermakna bahwa kepercayaan diri merupakan ciri dari sebuah harapan yang tinggi untuk mencapai keberhasilan. Hal tersebut dapat membantu para individu untuk mengembangkan emosi positif, mempermudah konsentrasi, menentukan sasaran, meningkatkan usaha, fokus pada strategi pertandingan, dan memelihara momentum. Pada dasarnya, kepercayaan diri dapat mempengaruhi sikap, perilaku, dan pengetahuan.

Berdasarkan beberapa pendapat di atas dapat disimpulkan bahwa orang yang mempunyai kepercayaan diri tinggi adalah orang yang yakin akan kemampuan dirinya sendiri, dan bersifat mandiri dalam arti tidak suka meminta bantuan orang atau pihak lain, dan orang yang percaya pada kemampuan dirinya sendiri berarti orang tersebut menghargai dirinya sendiri.

Menurut penelitian Soemanto dan Wasty (2003) pengenalan seseorang terhadap hasil atau kemajuan belajarnya adalah penting, karena dengan mengetahui hasil-hasil yang sudah dicapai maka siswa akan lebih berusaha meningkatkan hasil belajarnya. Sehingga dengan demikian peningkatan hasil belajar dapat lebih optimal karena siswa tersebut merasa termotivasi untuk meningkatkan hasil belajar yang telah diraih sebelumnya.

Belajar memerlukan kesiapan rohani, ketenangan dengan baik. Apabila dirinci faktor rohani itu meliputi antara lain ; intelegensi, bakat, minat, motivasi, factor kesehatan mental dan tipe khusus seorang pelajar (Ahmadi, 2004). Gagne dkk. (1992) membagi lima kategori hasil belajar.

Pertama, keterampilan intelektual (intellectual skills). Belajar keterampilan intelektual berarti belajar bagaimana melakukan sesuatu secara intelektual.

Kedua, strategi-strategi kognitif (cognitive strategies). Strategi-strategi ini merupakan kemampuan yang mengarahkan prilaku belajar, mengingat, dan berpikir seseorang.

Ketiga, informasi verbal (verbal information). Belajar informasi verbal adalah belajar untuk mengetahui apa yang dipelajari baik yang berbentuk nama-nama objek, fakta-fakta, maupun pengetahuan yang telah disusun dengan baik.

Keempat, keterampilan motor (motor skills). Kemahiran ini merupakan kemampuan siswa untuk melakukan sesuatu dengan menggunakan mekanisme otot yang dimiliki. 
Kelima, sikap (attitudes). Sikap merupakan kemampuan mereaksi secara positif atau negatif terhadap orang, sesuatu, dan situasi.

Hasil belajar Gagne di atas hampir sejalan dengan pemikiran Bloom. Dalam hal ini, Bloom (19790 mengelompokkan tiga aspek hasil belajar yakni kognitif, afektif, dan psikomotor.

Belajar dapat dilihat dari tiga sudut pandang (Sudjana, 2000), yaitu :

1. belajar sebagai proses;

2. belajar sebagai hasil;

3. belajar sebagai fungsi

Ketiga sudut pandang ini penting untuk dipahami oleh guru. Belajar sebagai hasil dijadikan dasar dalam menyusun deskripsi teoretis hasil belajar. Dimyati dan Mudjiono (1999) membedakan evaluasi hasil belajar dengan evaluasi pembelajaran. Evaluasi hasil belajar menekankan pada informasi tentang seberapa jauh siswa telah mencapai tujuan pengajaran yang telah ditetapkan sedangkan evaluasi pembelajaran merupakan proses sistematis untuk memperoleh informasi tentang keefektifan proses belajar dalam membantu siswa mencapai tujuan pengajaran secara optimal.

Hamalik (2001) menyatakan prestasi belajar adalah hal-hal yang telah dicapai oleh seseorang. Ada dua faktor yang harus diperhatikan dalam melaksanakan evaluasi hasil belajar. Pertama, perbedaan potensi-potensi yang dibawa oleh siswa pada saat belajar: kesehatan fisik, kemampuan mental, kondisi emosional, minat dan kebutuhan, serta lingkungan rumah tangga dan sosial. Kedua, bermacam-macam tuntutan sosial dan ekonomi di sekitar kehidupan siswa di mana siswa berpartisipasi aktif di dalamnya (Crow dan Crow, 1987).

Dengan demikian hasil belajar pada dasarnya merupakan tujuan belajar yang berhasil dicapai oleh siswa. Tingkat ketercapaian tujuan belajar ini biasanya diukur dengan skor yang diperoleh siswa dalam menyelesaikan sebuah tes hasil belajar.

Mata pelajaran IPS mempelajari fakta, konsep, dan generalisasi. Kepahaman siswa terhadap tiga materi ini diukur berdasarkan tes hasil belajar pada aspek kognitif. Materi pelajaran IPS yang dijadikan isi tes hasil belajar berbentuk fakta, konsep, dan generalisasi yang baru dipelajari siswa melalui proses observasi dan inferensi yang dilakukan terutama pada saat pembelajaran mata pelajaran IPS di kelas. Materi pelajaran ini tidak menutup kemungkinan berasal dari pengalaman kehidupan sosial siswa baik di sekolah, di dalam keluarga, maupun di masyarakat.

Motivasi merupakan rangsangan yang timbul dari dalam individu untuk kemudian melakukan tindakan. Agar tindakan atau perilaku yang dilakukan sesuai dengan harapan, maka perlu diberi motivasi yang dapat mendorong individu melakukan tindakan yang diharapkan. Menurut (Siagian, 2004)

Hasil penelitian Peklaj and Levpušček (2005) harus mempertimbangkan motivasi siswa sebelum kita mulai bekerja pada tujuan pendidikan tertentu sangat hati-hati, terutama ketika mengembangkan kompetensi guru kompleks seperti presentasi dan kerjasama keterampilan pada saat yang sama. Kita dapat meningkatkan motivasi siswa dengan memilih yang relevan, masalah otentik yang berkaitan dengan profesi siswa masa depan dan dengan demikian memastikan akuntabilitas masing-masing. 
Sedangkan menurut V. Opit (2014) menunjukkan hasil penelitiannya yaitu Motivasi dan Analisis, baik parsial dan bersama-sama, memiliki efek positif pada Prestasi Pengajaran Perencanaan Pembelajaran dari mahasiswa Pendidikan Kesejahteraan Keluarga, Fakultas Teknik, Universitas Negeri Manado.

Sementara itu T. Aritonang (2008) dalam penelitiannya juga menunjukkan bahwa ada hubungan yang signifikan antara variabel motivasi belajar siswa terhadap hasil belajar yang diperoleh.

Menurut kesimpulan Asmawan (2009), penelitiannya ini adalah ada pengaruh signifikan antara keluarga dan penggunaan fasilitas belajar di rumah terhadap prestasi dari Siswa Kelas X Ekonomi di SMAN 1 Bululawang. Berdasarkan penelitian, disarankan bahwa orang tua harus meningkatkan perhatian terhadap anak-anak mereka dengan tetap mendidik mereka untuk secara teratur mempelajari, mengamati kemajuan dan prestasi mereka, memperhatikan kebutuhan mereka terutama yang berkaitan dengan sekolah mereka seperti buku materi, stasioner, dan fasilitas pendukung belajar di rumah.

Bangun (2008), menyimpulkan bahwa: (1) ada hubungan persepsi siswa tentang perhatian orang tua dengan prestasi belajar ekonomi siswa, (2) ada hubungan kelengkapan fasilitas belajar di rumah dengan prestasi belajar ekonomi. (3) ada hubungan penggunaan waktu belajar di rumah dengan prestasi belajar ekonomi, dan (4) ada hubungan persepsi siswa tentang perhatian orang tua, kelengkapan fasilitas belajar di rumah dan penggunaan waktu belajar di rumah dengan prestasi belajar ekonomi

Rasa percaya diri, merupakan bagian penting dari karakteristik kepribadian siswa yang dapat memfasilitasi kehidupannya, khususnya yang berhubungan dengan kegiatan belajar dan pencapaian tujuan belajar siswa.

Menurut Falk dan Sunde (2006) menyatakan bahwa orang-orang yang secara substansial tidak yakin apakah mereka adalah jenis dengan probabilitas tinggi atau rendah keberhasilan, ditentukan oleh berada di atas atau di bawah rata-rata dalam hal kemampuan.

Menurut Hebaish (2012) hasil penelitiannya menunjukkan hubungan yang positif dan signifikan antara umum kepercayaan diri dan prestasi akademik. Mereka yang mencetak tinggi di GSCQ juga memiliki nilai yang tinggi dalam tes prestasi lisan. Instruktur bahasa yang direkomendasikan untuk meningkatkan membangun siswa mereka rasa percaya diri untuk mengembangkan pencapaian kinerja lisan mereka. Penulis setuju dengan percaya diri dapat meninkatkan hasil belajar dengan cara pembiasaan dengan hal-hal yang positif.

Maferima (2011) membahas program motivasi dalam mengejar berbagai tujuan. Mereka membedakan antara dua dimensi motivasi: motivasi untuk mencapai tujuan focal (dimensi hasil-terfokus) dan motivasi untuk "melakukan hal yang benar" dalam proses mencapai tujuan itu (berarti berfokus dimensi). Kami mengidentifikasi kondisi di mana motivasi untuk mencapai tujuan peningkatan fokus terhadap penurunan selama mengejar tujuan. Mereka kemudian mengusulkan bahwa motivasi untuk "melakukan hal yang benar" mengikuti pola berbentuk $u$, sedemikian rupa sehingga lebih tinggi pada awal dan akhir mengejar gol. 


\section{SIMPULAN}

Berdasarkan uraian di atas, dapat disimpulkan bahwa: Ada pengaruh motivasi belajar terhadap hasil belajar IPS siswa penerima BSM (Bantuan Siswa Miskin) SMP Negeri di Surabaya. Motivasi belajar yang dimiliki siswasiswa dalam setiap kegiatan saat pembelajaran sangat berperan dalam meningkatkan hasil belajar siswa dalam mata pelajaran tertentu. Selain itu motivasi belajar juga merupakan kebutuhan untuk mengembangkan kemampuan diri secara optimum, sehingga mampu berbuat yang lebih baik, berprestasi dan kreatif.

Ada pengaruh sarana belajar terhadap hasil belajar IPS siswa penerima BSM (Bantuan Siswa Miskin) SMP Negeri di Surabaya. Sarana belajar merupakan faktor eksternal yang sangat mempengaruhi hasil belajar siswa. Fasilitas belajar yang lengkap dan tepat akan memudahkan siswa dalam menerima dan menguasai pelajaran, siswa yang memiliki sarana belajar memadai, akan mendukung hasil belajar dan termotivasi serta berminat untuk belajar lebih giat.

Ada pengaruh percaya diri terhadap hasil belajar IPS siswa penerima BSM (Bantuan Siswa Miskin) SMP Negeri di Surabaya. Percaya diri merupakan bagian penting dari karakteristik kepribadian siswa yang dapat memfasilitasi kehidupannya, khususnya yang berhubungan dengan kegiatan belajar dan pencapaian tujuan belajar siswa.

Berdasarkan analisis data yang telah dilakukan, diperoleh hasil bahwa motivasi belajar, sarana belajar, dan percaya diri secara simultan berpengaruh positif terhadap hasil belajar siswa, sehingga dapat didiskripsikan bahwa semakin baik motivasi belajar siswa, sarana belajar, dan percaya diri, maka semakin baik pula hasil belajar IPS siswa penerima BSM (Bantuan Siswa Miskin) SMP Negeri di Surabaya.

\section{DAFTAR RUJUKAN}

Ahmadi, A. (2004). Psikologi Sosial. Belajar.138 Jakarta. PT Rineka cipta

Anonim (2006). Panduan Kurikulum Tingkat Satuan Pendidikan (KTSP) SD/MI. Jakarta: BP Dharma Bhakti

Djalil, Aria. (2003). Pembelajaran Proses Belajar Mengajar. Jakarta: Bumi Aksara

Falk, Armin, Huffman, David, Sunde, Uwe (2006). Self-Confidence and Search Percaya Diri dan Pencarian

As'ad, Moh. (2003). Interaksi dan Motivasi Belajar Mengajar Manajemen SDM. PT Jakarta. Universitas Trisakti

Asmawan, Bahrul Fuad. (2009). The effect of Family and the Usage of Learning Facilities at Home toward the Achievement of 10th Grade Students on Economics in SMAN 1 Bululawang. Education of Economics program, Faculty of Economics, State University of Malang 
Bloom, Benjamin. (1979) Taxnomi of Educational Objectives book. Domain. London. Longman Group

Branden, Nathaniel (2006). Kiat Jitu Meningkatkan Harga Diri (alih bahasa oleh tim redaksi Mitra Utama). Jakarta: Delapratasa

Crow L. \& A. Crow (1987). Psiklogi Pendidikan. Surabaya: Bina Ilmu

Bangun, Darwin. (2008). Hubungan persepsi siswa tentang perhatian orang tua, dan penggunaan waktu belajar di rumah kelengkapan fasilitas belajar dan penggunaan waktu belajar di rumah dengan prestasi belajar ekonomi.

Peklaj, Cirila and Levpušček, Melita Puklek (2005). Article Students' motivation and academic success in relation to the quality of individual and collaborative work during a course in educational psychology. Association Of Teacher Education in Europe

Cox, H.R. (2002). Sport Psychology Concepts and Aplication. Dubucue:WmC Brow Publisher

Dimyati, Mudjionoo (1999). Belajar dan Pembelajaran. Jakarta: Reneka Cipta

Gagne, R.M., Briggs, L.J., dan Wager, W.W. (1992). Principles of Instructional Design. New York, Holt Rinehart

Hebaish, (2012). The Correlation between General Self-Confidence and Academic Achievement in the Oral Presentation Course. Department of Curricula and Teaching Methods. Kingdom of Saudi Arabia

Huitt, W. (2004). Maslow's Hierarchy of Need. Education's Psychology Interactive aldosta, GA: Valdosta State University.

Iskandar, (2009).Psikologi Pendidikan. Belajar Mengajar.141.Ciputat. Gaung Persada

Keputusan Mendiknas. (2003). Nomor 053/V/2001, tentang "Pedoman Penyusunan Standar Pelayanan Minimal Penyelenggaraan Persekolahan Bidang Pendidikan Dasar dan Menengah" (2003),

Maferima Touré-Tillery *, Ayelet Fishbach. (2011). The course of motivation. Journal of Consumer Psychology xx (2011) xxx-xxx

Moisi, Dominique. (2006). Self Confident. http://en.wikipedia/org/self confident

Mulyasa. (2005). Manajemen Berbasis Sekolah. Jakarta : Depdiknas.

Nashar, (2004). Peranan Motivasi dan Kemampuan awal dalam kegiatan Pembelajaran. Jakarta: Delia Press.

Hamalik, Oemar (2001). Kurikulum dan Pembelajaran. Jakarta: PT Bumi Aksara

Saifudin, Anwar (2003). Sikap Manusia, Teori dan Pengukurannya. Yogjakarta. Pustaka Pelajar. 
Sardiman. (2011). Interaksi dan Motivasi Belajar Mengajar. Jakarta: Rajawali Pers

Siagian P. Sondang. (2004). Kiat Meningkatkan Produktivitas Kerja. Jakarta : Rineka Cipta.

Soemanto, Wasty. (2003). Psikologi Pendidikan. Malang: Rineka Cipta

Sudjana, N. (2000). Dasar-dasar Proses Belajar Mengajar. Bandung: Sinar Baru Algesindo

Sugiyono. (2011). Metode Penelitian kuntitatif Kualitatif dan R\&D. Bandung: Alfabeta.

T. Aritonang, Keke (2008). Minat dan motivasi dalam meningkatkan hasil belajar siswa.Researchgate No. 265217011

Undang - Undang Republik Indonesia Nomor 20 Tahun 2003 tentang Sistem Pendidikan Nasional. Jakarta : Depdiknas.

V. Opit, Helena. (2014). Article Motivation and Activity Analysis for Improving Learning Achievement of Teaching Planning in State University of Manado. IJERN Vol. 2 No. !0 October 2014

Weinberg, Robert S. Gould, Daniel. (2003). Fundation of Sprt Exercise psychology third edition. Compaign II. Human Kinetics Publisher

Wlodkowski R.J, dan Jaynes, J.H. (2004). Motivasi Belajar. Jakarta:Cerdas Pustaka.

Zulkarnain, Iskandar. (2007). Jurnal Deklarasi Asosiasi Pengusaha Sarana Pendidikan Indonesia 